\title{
Tren Desain Furnitur Berbahan Limbah Kayu di Media Jual Beli Daring
}

\author{
Mahendra Nur Hadiansyah ${ }^{1}$, Alieviatara Yathallayov ${ }^{2}$ \\ ${ }^{1,2}$ Desain Interior, Fakultas Industri Kreatif, Universitas Telkom \\ mahendrainterior@telkomuniversity.ac.id ${ }^{1}$, alieviya@telkomuniversity.ac.id ${ }^{2}$
}

\begin{abstract}
ABSTRAK
Limbah kayu merupakan jenis limbah yang berasal dari pohon atau hasil hutan alami ataupun produksi industri. Secara umum pepohonan memberikan dampak positif bagi berbagai kebutuhan manusia, karena secara spesifik batang kayu yang utuh hingga yang telah diolah memiliki nilai yang dapat terhitung dan tidak bisa terhitung bagi manusia. Selain itu, dalam perekonomian berbagai jenis kayu baik itu berukuran utuh maupun serbuk, berukuran besar maupun kecil. Semua jenis kayu tersebut dapat dimanfaatkan oleh manusia. Namun, saat ini di Indonesia khususnya dalam pengolahan berbagai bentuk limbah baik berukuran besar maupun kecil masih belum dimanfaatkan semaksimal mungkin, hal ini terjadi karena kurangnya kreativitas dan kepedulian masyarakat Indonesia dalam mengolah limbah tersebut. Dengan adanya permasalahan tersebut maka cara menanggulanginya adalah dengan memanfaatkan limbah kayu menjadi produk yang bernilai tambah dan dapat bermanfaat untuk lingkungan dan masyarakat. Dalam penelitian ini dilakukan dengan melakukan wawancara pengrajin dilanjutkan dengan kuisioner kepada masyarakat dan juga melakukan analisis pada furniture limbah yang paling banyak dibeli pada media daring seperti Bukalapak. Berdasarkan hasil penelitian ini didapati bahwa masyarakat akan lebih memilih untuk berbelanja secara langsung ke toko. Namun, karena adanya pandemic Covid-19 membuat masyarakat mau tidak mau membeli furnitur secara daring dengan beberapa pertimbangan, selain itu dalam pemilihan furnitur dari limbah kayu masyarakat memilih dari material kayu palet didasari karena kayu ini lebih bersih dari sisi warna dan juga mudah untuk ditata sesuai dengan interior yang ada dimana dengan penggunaan furnitur dari kayu palet ini akan membuat ruang terlihat pada penggayaan rustic apabila melalui proses pelapisan akhir yang cukup detail, namun tak menutup kemungkinan bahwa kayu palet akan lebih terekspos dan membuat ruangan menjadi lebih indah.
\end{abstract}

Kata kunci: Limbah Kayu; Furnitur; Tren; Desain

\section{ABSTRACT}

Wood waste is a type of waste derived from trees or natural forest products or industrial production. In general, the trees have a positive impact on a variety of human needs, because specifically the stem of wood intact to the one that has been Dilah has the value of tangible and intangible for humans. In addition, in the economy of various types of wood both intact and powder, large and small. All types of wood can be utilized by humans. However, nowadays in Indonesia especially in the processing of various forms of waste both large and small is still not utilized to the fullest, this is due to lack of creativity and awareness of the people of Indonesia in processing the waste. With this problem, the way to mitigate it is to utilize wood waste into a value-added product and can be beneficial for the environment and society. In this research, the methods by conducting interviews the craftsmen continued with the questionnaire to the community and also conducted analysis to the most purchased waste furniture on online platforms such as Bukalapak. Based on the results of the study stated that the public would prefer to shop directly to the store. However, because of the pandemic Covid-19 make the community will not want to buy furniture online with some considerations, other than that in the selection of furniture from wood waste people choose from wood pallet material based on wood that is more clean than the side of the color and also easy to cultivate wooden pallets according to the existing interiors where the use of furniture from wood pallets will make the room visible on the natural styling when through a fairly detailed finishing process, but did not close the possibility that the wooden pallets will be made exposed and make the room more beautiful.

Keyword: Wood Waste; Furniture; Trend; Design 


\section{PENDAHULUAN}

Pemanfaatan limbah kayu di lingkungan masyarakat masih kurang dimanfaatkan dengan baik. Salah satu contoh pemanfaatkan limbah kayu di lingkungan masyarakat yaitu digunakan sebagai bahan bakar rumah tangga, dimana pemanfatan tersebut juga berdampak buruk bagi lingkungan. Sejak dahulu limbah kayu ini sudah tak awam lagi bagi masyarakat untuk ditanggulangi, masyarakat yang telah memikirkan bagaimana limbah kayu dapat dimanfaatkan untuk diproses menjadi sebuah material baru yang bermanfaat yaitu papan partikel yang memanfaatkan limbah serbuk kayu (Cahyandari, 2007). Jenis furnitur yang memanfaatkan limbah kayu baik itu berupa serbuk maupun limbah kayu bekas dapat disebut dengan reclaimed furniture (reklamasi), furnitur reklamasi merupakan salah satu furnitur dalam penerapan konsep green furniture. Dimana tren frnitur limbah ini dapat disebut sebagai eco-label atau produk berwawasan lingkungan sehat (Aristeus, 2019).

Pemanfaatan limbah kayu difokuskan pada furnitur karena furnitur dalam dunia interior telah menjadi faktor pedukung utama dalam perwujudan konsep ruang dan menjadi salah satu faktor penentu selera pengguna. Dengan adanya perubahan jaman merupakan salah satu tanda bahwa tren juga ikut berubah pada masyarakat seperti tren interior, makanan, minuman, fashion, elektronik maupun furnitur. Namun, tak juga menutup kemungkinan bahwa tren lama akan kembali populer ataupun menjadi tren gabungan antara tren lama dan tren saat ini (Naimah, 2020). Dewasa ini tren interior yang sedang populer yang sering dijumpai di kafetaria ataupun restoran yaitu tren desain interior rustic, industrial dan juga scandinavian. Dimana tren interior tersebut banyak menggunakan furnitur khas dengan material kayu seperti penggunaan kayu palet bekas ataupun potongan kayu utuh. Dimana penggunaan kayu tersebut dalam interior juga banyak dijumpai pada furnitur yang difinishing dan juga tanpa finishing (Sutarman, 2016). Karena adanya tren desain interior yang banyak menggunakan material dasar kayu tersebut dan ditambah juga dengan semakin berkembangnya media jual beli barang secara daring yang menjadi tren baru masyarakat masa kini (Prasetya, 2017).

Menurut CNN Indonesia (2019), masyarakat di Indonesia yang telah memanfaatkan internet pada tahun 2018 tercatat sebanyak 171,17 juta pengguna dan $44 \%$ diantaranya sudah pernah melakukan belanja secara daring. Hal tersebut seiring waktu juga semakin meningkat hingga saat ini. Dapat disimpulkan bahwa penjualan secara daring saat ini memang sudah menjadi salah satu media yang menguntungkan karena pemasarannya mudah dijangkau banyak pihak. Untuk barang yang dapat dijual di media daringpun tidak terbatas mulai dari makanan, pakaian hingga furnitur dapat dijual secara daring. Sistem jual beli barang secara daring menjadi tren pada saat ini karena sangat memudahkan masyarakat di dunia saat ini (Nelly, 2019).

Berdasarkan kondisi yang telah dijabarkan di atas, maka perlu ditelusuri solusi yang tepat yang telah banyak dilakukan para perajin furnitur berbahan limbah kayu (reklamasi) dalam memanfaatkan limbah kayu tersebut sehingga bermanfaat bagi masyrakat dan lingkungan. Tentunya hal tersebut akan berdampak pada minat dan ketertarikan masyakat akan produk reklamasi tersebut ketika dijual melalui media daring sehingga mampu meningkatkan daya jual produk tersebut. Secara tidak langsung desain dari yang disiapkan dan diimplementasikan terhadap material limbah kayu oleh perajin sangat berpengaruh. Sehingga produk reklamasi yang dihasilkan mampu bersinergi dengan konsep atau tema yang ada yang kini banyak menjamur dikalangan masyarakat baik ruangan yang difungsikan secara komersial maupun non-komersil.

\section{METODE PENELITIAN}

\section{A. Metode Pengumpulan Data}


Metode yang digunakan dalam mengumpulkan data pada penelitian ini dilakukan dengan dua cara, dimana data pertama didapatkan dari hasil wawancara kepada pengrajin furnitur berbehan dasar kayu dan melakukan survey kepada msyarakat untuk mengetahui seberapa sering masyarakat berbelanja daring dan seberapa besar kemungkinan masyarakat untuk berbelanja furniture secara daring. Penyebaran kuisioner dibuat setelah melakukan wawancara kepada pengrajin furnitur untuk mengetahui bahan dasar limbah apa yang biasanya digunakan pada pembuatan furnitur tersebut, setelah itu dari material limbah itu dilakukan survey kepada masyarakat mana yang lebih diminati untuk digunakan sebagai bahan dasar membuat furnitur pada hunian responden. Lalu data kedua didapatkan dari hasil analisis terhadap produk-produk di media jual beli daring seperti Bukalapak dengan melakukan pengamatan terhadap desain yang ada dan komentar dari pembeli.

\section{B. Pengumpulan Data}

Pada awalnya data diperoleh dengan melakukan waswancara kepada pengrajin furnitur yang sering menggunkan limbah kayu untuk bahan dasar mereka, wawancara dimaksud untuk mendapatkan apa saja material yang sering dignakan oleh para pengrajin furnitur ini dan dari mana mereka mendapatkan limbah kayu tersebut. Selain itu juga, pengumpulan data didapatkan dari hasil penyebaran kuisioner kepada masyarakat secara daring untuk mengetahui seberapa besar minat masyarakat untuk berbelanja daring dan material limbah kayu apa yang lebih banyak diminati oleh responden jika dijadikan sebuah material utama dalam pembuatan furnitur.

\section{Analisis Data}

Analisis data diakukan dengan penelusuran, pengumpulan, serta pengamatan terhadap produk-produk furnitur berbahan dasar dari limbah kayu pada media jual beli daring. Untuk mengatahui bagaimanakan desain dan implementasi material limbah kayu pada produk terlaris dalam penjualan daring yang ada pada beberapa akun media jual beli daring.

\section{HASIL PENELITIAN DAN PEMBAHASAN}

\section{A. Jenis Limbah Kayu yang Diminati dan Digunakan oleh Perajin Furnitur}

Perkembangan dalam hal pengerjaan dan pengolahan kayu berjalan dengan pesat, lebihlebih karena Indonesia memiliki kekayaan akan aneka jenis kayu (Dumanauw, 2001). Hal itu juga mengakibatkan banyaknya perusahaan pengrajin dengan berbahan dasar kayu dimana dari pengrajin itu juga banyak menghasilkan limbah seperti serbuk kayu dimana belum banyak masyarakat yang memanfaatkan limbah serbuk kayu tersebut, dengan berjalannya waktu limbah kayu tersebut dapat dimanfaatkan dengan membuat limbah kayu menjadi papan partikel yang dapat dimanfaatkan oleh masyarakat (Cahyandari, 2007). Dengan berkembangnya jaman saat ini dimana bisnis furniture di Indonesia mangalami perkembangan cukup dinamis. Hal ini ditandai dengan munculnya beberapa desainer yang menaruh perhatian serius pada upaya pengembangan desain furnitur dengan tren terbaru, mereka mencri bentuk dan pendekatan baru yang sedikit banyak dipengaruhi tren desain furnitur dunia dengan pengembangan desain furnitur berbahan kayu (Jamaludin, et.al, 2018). Selain itu perkembangan desain furnitur juga didukung dengan semakin berkembangnya teknologi dengan munculnya situs atau aplikasi perdagangan electronic (e-commerce) yang menjadi sebuah perjalanan perdaganagan secara digital yang memanfaatkan teknologi internet, sehingga transaksi jual beli produk dan jasa dapat berlangsung secara efektif, efisien, ekonomis jika dibandingkan dengan cara konvensional selama ini (Sugara, 2017). 
Sebagian besar para perajin furnitur selain berjualan dengan memajang produk di toko yang dimiliki juga melakukan penjualan melalui media jual beli daring. Tren pasar daring furnitur berbahan limbah kayu menunjukan ada dua material limbah kayu yang diminati oleh konsumenya. Hal tersebut ditunjukan dari jumlah pembelian terbanyak dan komentar positif yang dilontarkan pada kolom komentar. Pertama yang banyak diminati oleh masyarakat yaitu penggunaan limbah kayu yang berasal dari kapal atau perahu yang sudah tidak digunakan oleh para nelayan atau bangkai dari kapal/perahu yang sudah rusak. Para pengrajin furnitur ini mendapatkan material limbah dari pesisir pantai atau dengan membeli material limbah kayu ini yang tergolong sangat murah namun dapat memberikan keuntungan yang signifikan. Selain itu juga terdapat pengrajin furnitur yang menggunakan limbah kayu yang berasal dari peti kayu yang biasanya digunakan untuk membungkus barang-barang jual beli secara expor atau impor. Barang tersebut biasanya yang berbobot besar atau rawan kerusakan seperti barang elektronik, keramik, atau bahan makanan dalam jumlah besar. Dalam penanganan awal bahan baku limbah kayu dari kapal atau perahu bekas maupun kayu palet tidak ada langkah-langkah khusus, namun biasanya jika limbah kayu sudah terlanjur dalam keadaan berjamur biasanya dibersihkan terlebih dahulu lalu dijemur di bawah panas terik matahari.

\section{B. Respon Konsumen}

Minat masyarakat dalam berbelanja secara daring sangat tinggi dan semakin meningkat ketika pemerintah Indonesia mengumumkan bahwa Indonesia darurat virus Covid-19 yang mengharuskan masyarakat seminim mungkin melakukan kegiatan di luar rumah. Dari 69 orang, sebanyak $85,5 \%$ yang didapatkan menyatakan bahwa mereka sering berbelanja secara daring. Namun, jangka waktu mereka berbelanja daring 72,5\% dari mereka hanya berbelanja setidaknya sebulan sekali, dan terdapat $2,9 \%$ responden menyatakan bahwa mereka melakukan pembelian daring hampir setiap hari terlebih saat pandemi melanda negeri Indonesia.

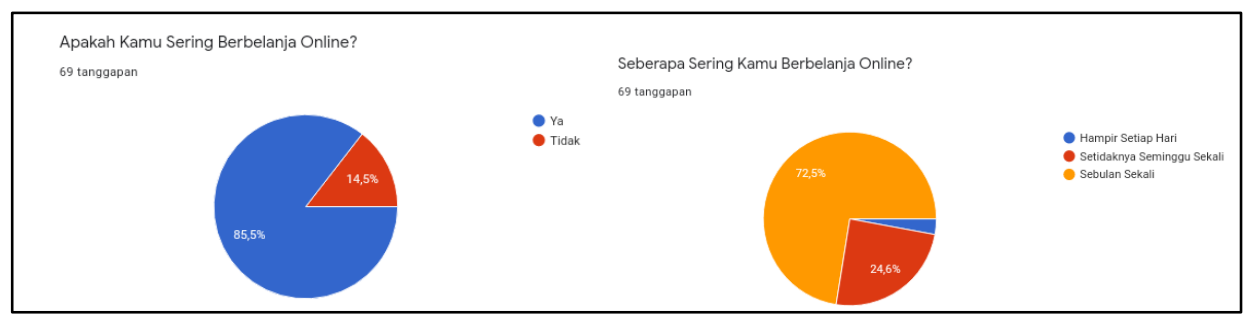

Gambar 1. Diagram Minat Belanja Online Sumber: Data Penulis (2020)

Sedangkan minat masyarakat untuk berbelanja furnitur, mereka lebih memilih untuk berbelanja secara langsung ke toko dibandingkan secara daring. Sebanyak 53,6\% menyatakan bahwa berbelanja secara langsung di toko furnitur dirasa lebih diminati dibandingkan dengan berbelanja secara daring. Hal tersebut dikarenakan calon konsumen dapat merasakan langsung secara fisik seperti menyentuh materialnya, merasakan kenyamananya, mengukur detail dimensinya, melihat langsung warna dan coraknya, serta dapat membayangkan kesesuaian desain furnitur yang akan ditempatkan dalam ruangan yang akan diisi nantinya. Namun, tak sedikit pula masyarakat yang berminat untuk berbelanja furnitur secara daring tetapi dengan pertimbangan tertentu. Pertimbangan tersebut seperti halnya adalah kepraktisan tanpa harus mendatangi langsung ke toko furnitur, menggunakan pembayaran secara daring, produk yang dibeli akan diantar langusung ke tujuan yang diinginkan pembeli sehingga sangan minim melakukan kontak fisik secara dekat dengan orang lain. Terlebih seperti kondisi saat ini tahun 
2020 yang menuntut para konsumen untuk sebisa mungkin berbelanja dari rumah saja saat masa pandemi Covid-19 berlangsung.

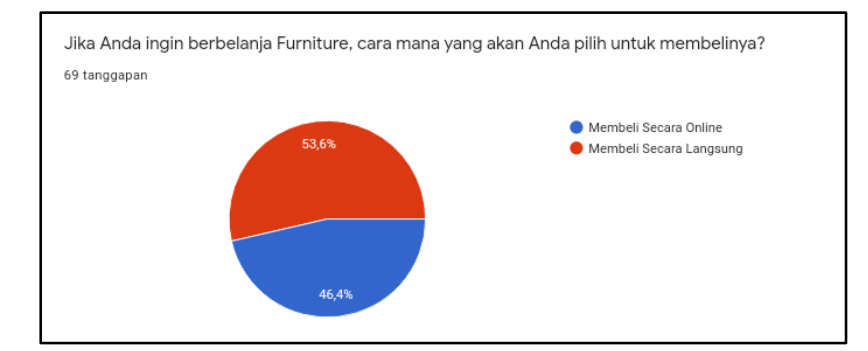

Gambar 2. Diagram Minat Berbelanja Furnitur Secara Daring Sumber: Data Penulis (2020)

Telah diketahui sebelumnya bahwa furnitur berbahan limbah kayu yang paling diminati di media jual beli daring oleh konsumenya adalah berbahan limbah kayu bekas kapal atau perahu dan furnitur berbahan limbah kayu palet yang berasal dari sisa kemasan barang rawan rusak atau pecah dalam peti kemas yang dikirim secara export atau impor. Hal ini sejalan dengan pilihan beberapa masyarakat awam yang melihat dan membandingkan secara visual melalui foto dari desain kedua furniture berbahan limbah kayu tersebut yang menunjukan sebanyak $76,4 \%$ lebih memilih furnitur berbahan dasar kayu palet lebih menarik dan menggugah keinginan untuk masuk dalam rencana pembelian furnitur. Hal tersebut menunjukan furnitur kayu palet lebih diminati yang sebanding hasilnya dengan informasi yang ada pada media jual beli daring bahwa jumlah penjualan lebih banyak furnitur kayu palet dibandingkan furnitur kayu bekas kapal atau perahu.

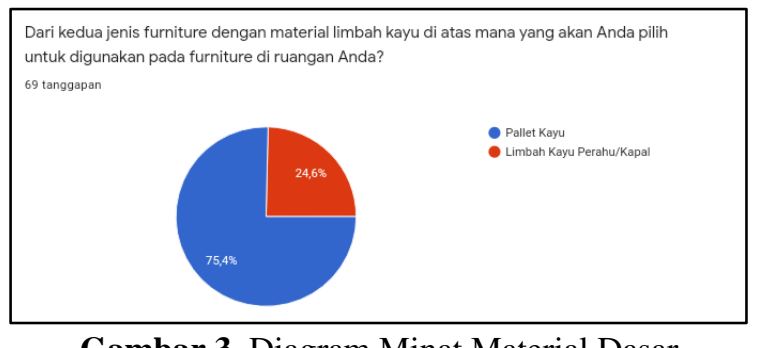

Gambar 3. Diagram Minat Material Dasar Sumber: Data Penulis (2020)

Furnitur berbahan limbah kayu palet lebih diminati dikarenakan material kayu palet memiliki tampilan yang lebih bersih dan rapih, lebih terlihat natural karena motif serat kayu lebih terlihat dan terekspos, serta lebih mudah untuk dipadu padankan dengan kondisi ruangan maupun perabot lainya yang ada. Sedangkan furnitur berbahan limbah kayu bekas perahu atau kapal lebih cenderung terkesan tidak rapih dan kotor yang muncul dari warna cat sisa dari pengecatan pada kapal atau perahu. Hal tersebut juga menyebabkan kesan natural kayu juga hilang secara visual. Kondisi itulah yang membuat para konsumenya lebih memiliki kalangan dan pengguna yang terbatas karena hanya cocok dengan kondisi dan konsep interior tertentu saja tidak sefleksibel tampilan material kayu palet.

\section{Desain Furnitur Berbahan Limbah Kayu Terlaku di Media Jual Beli Daring}

Berdasarkan hasil penelusuran di Google Tren terhadap minat masyrakat terhadap proses jual beli secara daring khususnya pada pembelian furnitur berbahan limbah kayu, menunjukan bahwa terhitung bulan Juli 2018 sampai Juli 2020 terdapat polularitas penelusuran tertinggi terhadap produk-produk furnitur yaitu berada pada pertengahan bulan April 2020 yang disusul pada awal bulan Juni 2020, hal ini diakibatkan adanya panic buying pada pertengahan bulan 
April 2020 yang diakibatkan karena adanya wabah Covid-19 yang mengakibatkan meningkatnya kebutuhan furnitur bernilai estetik namun berharga murah. Kondisi tersebut pada akhirnya mengarahkan calon konsumen menuju laman-laman akun jual beli daring yang menawarkan produk furnitur berbahan limbah kayu. Seperti yang tercermin pada grafik berikut:

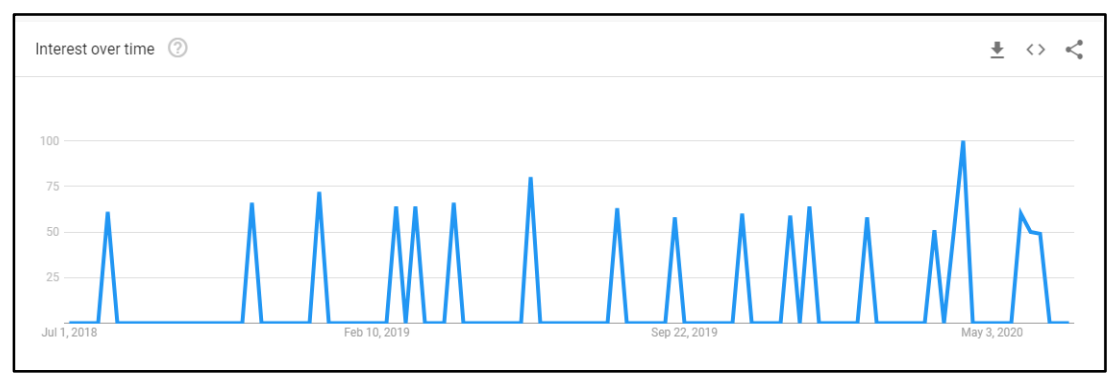

Gambar 4. Hasil Survey Tren Varian Olahan Limbah Kayu Sumber: https://trends.google.com/ (2020)

Hasil catatan transaksi pada beberapa media jual beli daring juga menunjukan adanya peningkatan penjualan produk pada beberapa akun jual beli daring didalamnya yaitu salah satunya Gendhismadu Galeri dengan banyak sekali komentar positif dari pembelian furnitur berbahan kayu yang meningkat sejak adanya pandemi Covid-19 ini. Gendhismadu Galeri adalah salah satu toko daring furnitur berbahan kayu solid yang menawarkan juga beberapa produk berbahan limbah kayu. Pemasaran secara daring merupakan media yang dirasa sangat tepat untuk mendapatkan konsumen dan juga dapat berguna untuk membangun suatu citra produk yang dijual, selain itu pemasaran secara daring juga tak terbatas oleh konsumen local saja namun juga dapat menjangkau konsumen di seluruh dunia.

Selain Gendhismadu Galeri ada salah satu akun jual beli daring yang cukup konsisten dengan produk-produk yang berbahan limbah kayu bekas kapal atau perahu yaitu Mayasa Galeri, sedangkan yang konsisten dengan penjualan produk furnitur berbahan limbah kayu palet adalah furnituremeubelonline catatan penjualan pada kedua akun toko tersebut pada media jual beli daring juga menunjukan tingkat penjualan yang cukup baik serta banyak komentar pembeli yang memberikan kesan baik terhadap pelayanan maupun produk yang telah dibeli. Berikut merupakan desain dari produk-produk terlaku pada media jual beli daring dari toko-toko tersebut:

Tabel 1. Deskripsi Desain Furnitur Berbahan Material Limbah Kayu Bangkai Kapal dan Kayu Palet

\begin{tabular}{|c|l|l|l|}
\hline NO & MATERIAL & FOTO PRODUK & \multicolumn{1}{|c|}{ DESKRIPSI DESAIN } \\
\hline 1 & $\begin{array}{l}\text { Kayu Limbah } \\
\text { Perahu }\end{array}$ & $\begin{array}{l}\text { Desain furnitur dengan } \\
\text { material dasar kayu limbah } \\
\text { perahu ini memiliki ciri } \\
\text { khas yang menarik yang } \\
\text { berasal dari warna asli dari } \\
\text { perahu yang dipertahankan } \\
\text { oleh para pembuatnya. } \\
\text { Selain warna juga ada } \\
\text { lubang-lubang bekas pasak }\end{array}$ \\
\hline
\end{tabular}




\begin{tabular}{|c|c|c|c|}
\hline NO & MATERIAL & FOTO PRODUK & DESKRIPSI DESAIN \\
\hline & & $\begin{array}{c}\text { Sumber: } \\
\text { https://www.bukalapak.com/u/ } \\
\text { mayasa_gallery }\end{array}$ & $\begin{array}{l}\text { warna hitam bekas oli dan } \\
\text { bahkan masih ada kerang } \\
\text { kecil yang menempel. } \\
\text { Selain untuk ciri khas dari } \\
\text { furniture ini juga untuk } \\
\text { membuat furnitur terlihat } \\
\text { lebih alami bahwa furniture } \\
\text { ini berasal dari limbah } \\
\text { perahu. Dari desain yang } \\
\text { terlihat desain furnitur ini } \\
\text { cenderung pada penggayaan } \\
\text { retro. Untuk bentuk furnitur } \\
\text { cenderung menggunakan } \\
\text { bagian berwarna dijadikan } \\
\text { sebagai elemen dekoratif } \\
\text { pada permukaan tampilan } \\
\text { seperti yang terlihat pada } \\
\text { meja, lemari, dan kursi, } \\
\text { limbah kayu kapal tersusun } \\
\text { sebagai pembentuk corak } \\
\text { bukan sebagai konstruksi } \\
\text { utama. Lain halnya dengan } \\
\text { bingkai cermin, susunan } \\
\text { kayu limbah menjadi } \\
\text { material konstruksi karena } \\
\text { produk ini tidak menerima } \\
\text { beban yang cukup berat. } \\
\text { pembuatan furnitur ini } \\
\text { mudah dibagian finishing } \\
\text { karena hanya perlu di } \\
\text { ampelas saja bahkan ada } \\
\text { beberapa pengrajin yang } \\
\text { tidak melakukan finishing } \\
\text { sama sekali namun cukup } \\
\text { rumit dibagian penyusunan } \\
\text { awal karena harus } \\
\text { mengkombinasikan pecahan } \\
\text { material limbah kayu yang } \\
\text { ada. Pemanfaatanya pun } \\
\text { beragam mulai dari menjadi } \\
\text { konstruksi utama Maupin } \\
\text { dikombinasikan dengan } \\
\text { material lain seperti kayu } \\
\text { lain atau besi. }\end{array}$ \\
\hline
\end{tabular}




\begin{tabular}{|c|c|c|c|}
\hline NO & MATERIAL & FOTO PRODUK & DESKRIPSI DESAIN \\
\hline 2 & Kayu Palet & $\begin{array}{c}\text { Sumber: } \\
\text { https://www.tokopedia.com/fur } \\
\text { nituremeubel }\end{array}$ & $\begin{array}{l}\text { Desain furniture berbahan } \\
\text { dasar kayu palet bekas ini } \\
\text { pada dasarnya dapat dibuat } \\
\text { sesuai dengan keinginan } \\
\text { sendiri. apabila ingin } \\
\text { mempertahankan warna } \\
\text { aslinya dan memberikan } \\
\text { sedikit finishing maka } \\
\text { desain yang lebih monjol } \\
\text { adalah desain dengan } \\
\text { suasana industrial dan } \\
\text { rustic. Tetapi tak banyak } \\
\text { juga pengguna yang } \\
\text { mengecat ulang kayu palet } \\
\text { ini untuk menyesuaikan } \\
\text { dengan interiornya } \\
\text { contohnya seperti pada } \\
\text { produk meja makan. } \\
\text { Meskipun sudah di cat } \\
\text { ulang pada kaki ciri khas } \\
\text { dari papan kayu yang } \\
\text { tersusun sejajar ini secara } \\
\text { tidak langsung tetap } \\
\text { menjadi ciri khas utama } \\
\text { yang ditonjolkan. } \\
\text { Sedangkan untuk bentuk } \\
\text { dari furnitur dari palet kayu } \\
\text { ini cenderung berbentuk } \\
\text { kotak atau persegi dimana } \\
\text { bentuk tersebut } \\
\text { menyesuaikan bentuk } \\
\text { material awal yaitu } \\
\text { berbentuk papan persegi } \\
\text { panjang yang rata-rata } \\
\text { berketebalan } 2-3 \text { cm. } \\
\text { Walaupun bentuknya } \\
\text { terlihat lebih kaku dari } \\
\text { furnitur berbahan limbah } \\
\text { kayu kapal atau perahu, } \\
\text { furnitur palet kayu ini lebih } \\
\text { cenderung diminati karena } \\
\text { warnanya yang netral dan } \\
\text { dapat dipadukan dengan } \\
\text { berbagai gaya interior. Tak } \\
\text { jarang desainnya juga } \\
\text { dikombinasikan dengan } \\
\text { material lainya seperti besi }\end{array}$ \\
\hline
\end{tabular}




\begin{tabular}{|c|l|l|l|}
\hline NO & MATERIAL & FOTO PRODUK & \multicolumn{1}{|c|}{ DESKRIPSI DESAIN } \\
\hline & & & dengan dicat berwarna \\
& & hitam untuk mendapatkan \\
& & kesan atau konsep furniture \\
& & yang menyesuaikan dengan \\
& & kebutuhan suasana dalam \\
& & interior tertentu. Kombinasi \\
& & seperti itu biasanya banyaka \\
& & digunakan pada konsep \\
& & \\
& &
\end{tabular}

Sumber: Hasil Olah Data Penulis (2020)

\section{KESIMPULAN}

Sebagian besar para calon konsumen lebih cenderung memilih membeli furnitur secara langsung dengan melihat, memilih, dan merasakan langsung produk yang dijual di toko furnitur. Namun tak sedikit juga bagi para konsumen yang lebih memilih kepraktisan transaksi secara daring dan tinggal menunggu produk dikirim ke rumah pembeli. Utamannya pada tahun 2020 kondisi tersebut berbalik tingkat pembelian furnitur secara daring lebih tinggi dibandingkan dengan pembelian secara langsung di toko furniture. Hal tersebut disebabkan karena kondisi pandemic Covid-19 yang melanda diseluruh dunia sehingga menuntut masyarakat untuk tidak banyak beraktivitas di luar rumah.

Secara tren pasar yang didapatkan bahwa terdapat dua material limbah kayu yang digunakan pada produk furnitur yang diminati pada media jual beli daring yaitu kayu palet dan kayu bekas bangkai kapal atau perahu. Dari kedua limbah kayu tersebut yang lebih dominan diminati para konsumen adalah furnitur berbahan dasar kayu bekas palet. Hal tersebut karena furnitur limbah kayu palet secara penampilan lebih terlihat bersih, rapih dan natural menunjukan serat alami material asli kayu. Selain itu juga mudah dikombinasikan dengan material lainya guna menyesuaikan dengan kebutuhan konsep ruang tempat dimana furniture ini akan ditempatkan.

Dengan adanya informasi yang disampaikan diharapkan masyarakat lebih bisa memanfaatkan limbah-limbah kayu ataupun limbah lainnya untuk dapat digunakan sebagai furnitur ataupun karya serta produk yang berguna lainnya. Dengan didukung semakin berkembangnya media daring maka semestinya perkembangan untuk menghasilkan karya atau produk terbaru dari limbah akan semakin banyak lagi kedepannya.

\section{DAFTAR PUSTAKA}

Aristeus, S. (2019). Penerapan Ekolabel Dalam Produk-Produk Hutan Sebagai Upaya Lingkungan Hidup. Jurnal Penelitian Hukum De Jure. 19(4):421 December 2019.

Cahyandari, D. (2007). Pemanfaatan Limbah Kayu Sebagai Bahan Dasar Pembuatan Papan Partikel. Jurnal Traksi. Vol. 5. No. 1, Juni 2007.

CNN Indonesia (2019). 96 Juta Pengguna Internet Belum pernah Belanja Daring. Diakses dari: https://www.cnnindonesia.com/teknologi/20190516180707-192-395523/96-jutapengguna-internet-belum-pernah-belanja-daring. Pada 11 Agustus, Pukul 14.00.

Dumanauw, J. (2001). Mengenal Kayu. Yogyakarta: Kanisius

Jamaludin, Jamaludin and Kusnaedi, Iyus and Widia, Edwin (2018) Gaya Retro dan Ekplorasi Material dalam Tren Desain Mebel Karya Desainer Muda Indonesia. Panggung Jurnal Seni Budaya, 28 (3). 
Naimah. (2020). 6 Tren Gaya Arsitektur dan Interior Kekinian. Diakses dari: https://www.archify.com/id/archifynow/6-tren-gaya-arsitektur-dan-interior-yangkekinian pada 10 Agustus 2020, Pukul 12.35.

Nelly, K.F. (2019). hadirnya bukalapak dalam mempermudah proses jual beli online. Diakses dari: https://www.kompasiana.com/fredykusuma/5df0ba0bd541df587374ff42/hadirnyabukalapak-dalam-mempermudah-proses-jual-beli-secara-online?page=all. $\quad$ Pada 12 Agusus 2020, Pukul 15.00 WIB.

Prasetya, R. (2017). Potensi Limbah Kayu Industri Furnitur untuk Produk Aksesri. Jurnal Productum. Vol 1, No 1.

Sugara, A. (2017). Analisis Kepercayaan dan Kepuasan Terhadap Penggunaan Sistem Transasksi Jual Beli Online. Jurnal Administrasi Bisnis, Vol 52, no 1.

Sutarman, I. W. (2016) Pemanfaatan Limbah Industri Pengolahan Kayu di Kota Denpasar (Studi Kasus pada CV Aditya). Jurnal PASTI vol. 10, no. 1. 